\title{
PEMBINAAN SENTRA PRODUKSI TENUN SONGKET UNGGAN OLEH PEMERINTAH KABUPATEN SIJUNJUNG
}

\author{
Haryani Harsari \\ Jurusan Administrasi Publik, Fakultas Ilmu Sosial, Universitas Negeri Padang \\ Email : haryaniharsari96@gmail.com \\ Afrika Khaidir \\ Jurusan Administrasi Publik, Fakultas Ilmu Sosial, Universitas Negeri Padang \\ Email : af.khaidir@gmail.com
}

\begin{abstract}
Unggan Songket Weaving included one of the superior products in Sijunjung Regency its development is still not optimal. The type of research used this study is qualitative. The location of the study was conducted in Sijunjung and Sumpur Kudus Districts. The research informants used purposive sampling technique. While the data of this study are primary and secondary data. Techniques for collecting data on interviews, observation and documentation studies. Test the validity of the data in the study using source triangulation. The data analysis technique refers to the technique developed by Miles and Huberman. The results of this study indicate that the guidelines conducted by the government on Unggan weaving production centers can be seen from the role of the government that has been implemented, namely as a facilitator. regulator and catalyst. Constraints from developing the Unggan songket weaving center, namely capital, which is limited, lack of human resource management, and also weak business networks and Market Penetration Capability, and limited market access will cause products not to be marketed competitively both in the national market. and international markets. And finally, there are obstacles in the distribution and procurement of raw materials, limited access to information related to market opportunities and others.
\end{abstract}

Keywords: Coaching, Sentra, Unggan 


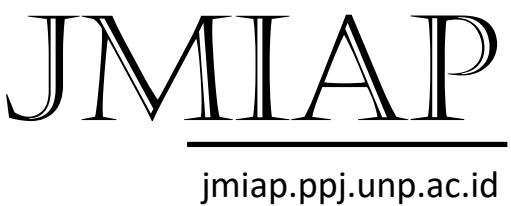

jmiap.ppj.unp.ac.id
JURNAL ILMU ADMINISTRASI PUBLIK

Email : jianfis.unp@gmail.com

Vol.1 No.1 Tahun 2018

\section{Pendahuluan}

Industri kecil merupakan suatu kegiatan strategis yang perlu mendapat perhatian baik oleh masyarakat maupun Pemerintah. Pengembangan industri kecil dapat meningkatkan pendapatan masyarakat yang pada akhirnya dapat meningkatkan kesejahteraan masyarakat. Industri kecil dan menengah (IKM) mempunyai peranan yang cukup penting di Indonesia. IKM mampu memberikan kontribusi bukan hanya dalam hal penyerapan tenaga kerja tetapi juga membuka peluang usaha yang cukup besar di daerah pedesaan. Selain itu pengembangan IKM di daerah mampu mengurangi ketimpangan ekonomi antar propinsi. Oleh karena itu Pemerintah memberikan perhatian yang cukup serius bagi pengembangan IKM. Salah satu upaya pemerintah dalam pengambangan IKM tersebut antara lain adalah pendekatan sentra industri. Pendekatan sentra industri kecil dan menengah merupakan salah satu kebijakan yang diterapkan Pemerintah untuk memajukan industri kecil dan menengah. Selain itu pemberdayaan UKM merupkan komponen yang penting penting juga seperti, dalam pengembangan UKM salah satunya dengan pembangunan prasarana produksi dan pemasaran, tersedianya prasarana pemasaran dan atau transportasi dari lokasi produksi ke pasar, akan mengurangi rantai pemasaran dan pada akhirnya akan meningkatkan penerimaan petani dan pengusaha mikro, pengusaha kecil, dan pengusaha menengah. Artinya, dari sisi pemberdayaan ekonomi, maka proyek pembangunan prasarana pendukung desa tertinggal, memang strategis.

Dalam mengembangkan usaha mikro kecil menengah di Kabupaten Sijunjung sekiranya perlu mendapat dukungan dari
Pemerintah Daerah sendiri salah satunya dalam meningkatkan kualitas Sumber Daya Manusiannya melalui pelatihan-pelatihan agar usaha yang di jalankan oleh masyarakat dapat berjalan dengan baik. Industri songket merupakan salah satu industri kerajinan yang menjadi produk unggulan di Kabupaten Sijunjung. Berdasarkan penelitian awal yang dilakukan di dinas Perdagangan Perindustrian Koperasi Usaha Kecil dan Menengah hingga tahun 2016 terdapat 4 Nagari di Kecamatan Sumpur Kudus yang memproduksi tenun songket antara lain Nagari Unggan, Nagari Sumpur Kudus, Nagari Sumpur Kudus Selatan dan Nagari Tanjung Bonai Aur, Namun hampir sebagian besar pengrajin tenun paling banyak terdapat di Nagari Unggan.

Sentra tenun Unggan perlu terus dikembangkan karena, kemampuan sumber daya manusianya perlu ditingkatkan lagi misalnya dalam hal mengolah kain tenun, untuk meningkatkan nilai jual kain tenun maka perlu di olah menjadi pakaian yang bernilai jual lebih oleh sebab itu keahlian seperti menjahit baju, keahlian mendesain baju, ataupun dikombinasikan dengan bordir harus ditingkatkan agar bisa meningkatkan nilai jual dari tenun songket Unggan yang dimuat di website Kabupaten Sijunjung 12 April 2017. Pemerintah telah memfasilitasi masyarakat dengan pembangunan gedung sentra untuk menunjang kegiatan masyarakat dalam menenun gedung sentra ini memiliki luas tanah sebesar 5.000 meter persegi dengan luas bangunan $15 \times 30$ meter persegi yang dilengkapi alat tenun sebanyak 20 unit yang bisa dipergunakan oleh tenaga kerja sebanyak 20 orang. Berdasarkan Peraturan Menteri Perindustrian RI No. 26/MIND/PER/2/2010 tentang Bantuan Peralatan dan atau Mesin maka tenun Unggan sebagai salah satu industri 


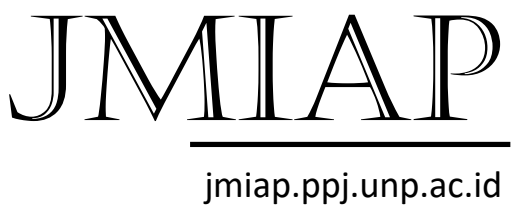

jmiap.ppj.unp.ac.id
JURNAL ILMU ADMINISTRASI PUBLIK

Email : jianfis.unp@gmail.com

Vol.1 No.1 Tahun 2018 unggulan di Kabupaten Sijunjung cukup dapat dipertimbangkan oleh Menteri Perindustrian RI untuk mendapatkan bantuan berupa lanjutan Pembangunan Sentra Songket Unggan.

Dengan seiring berjalannya waktu ditemui berbagai macam kendala di lapangan dalam pembinaan UKM, yang dimuat dalam Renstra Dinas Perdagangan Perindustrian Koperasi Usaha Kecil dan Menengah ada beberapa permasalahan dalam pengembangan UMKM salah satunya UKM tenun Unggan yaitu, terbatasnya akses permodalan bagi UMKM, sehingga sulit untuk melakukan pengembangan usaha, daya saing produk UMKM masih rendah, hal ini ditandai dengan rata-rata kurang bagusnya kualitas produk yang dihasilkan, harga kurang kompetitif dan pemasaran produk hanya sebatas pasar lokal, masih kurangnya ketersediaan penunjang usaha, terutama pemasaran dan informasi pasar, ketersediaan bahan baku dan sarana teknologi produksi.

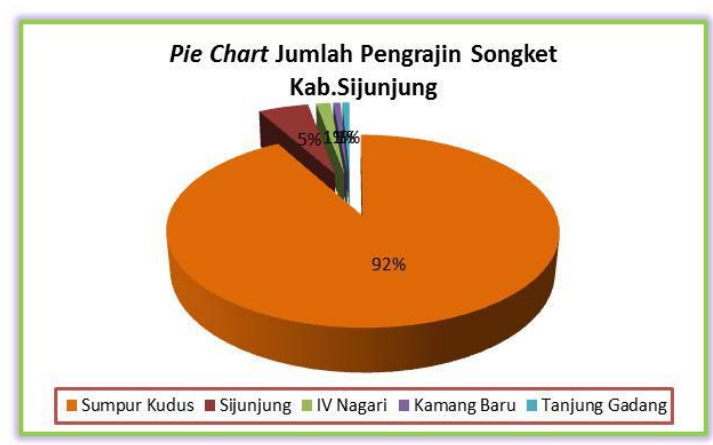

\section{Gambar. 1 proporsi pengrajin songket di Kabupaten Sijunjung}

Berdasarkan hasil pengamatan yang penulis lakukan di lapangan terkait dengan pembinaan sentra tenun songket Unggan oleh pemerintah di Kabupaten Sijunjung ditemui beberapa permasalahan dalam pembinaan tenun songket Unggan sebagai berikut: Pertama, dilihat dari segi sumber daya manusianya merubah kultur agraris menjadi industri dimana Pola pikir masyarakat di kecamatan Unggan masih bersifat agraris. Hal ini dikarenakan hampir semua masyarakat Unggan bertani untuk memenuhi kebutuhannya sehari-hari sehingga hal tersebut yang menyebabkan salah satu kendala dalam pembinaan sentra tenun songket Unggan oleh pemerintah kabupaten Sijunjung. Kedua, pengrajin tenun Unggan masih belum mandiri, dimana pengrajin tenun Unggan masih memasok bahan baku untuk menenun ke Silungkang sedangkan jarak dari Unggan ke Silungkang cukup jauh. Ketiga, pemasaran yang belum terlaksana dengan baik karena industri tenun Unggan belum mampu mengembangkan produksinya ke daerah lain disamping itu, outlet untuk peningkatan pemasaran tenun songket Unggan di Kabupaten Sijunjung juga belum ada yang menyebabkan pengrajin sedikit kesulitan untuk memasarkan hasil produknya. Keempat, kemampuan sumber daya pengrajin yang terbatas dan kurang inovatif dalam menghasilkan produk dari tenun songket Unggan dan juga banyaknya produk yang sejenis dipasaran yang lebih bagus. Kelima, masih belum maksimalnya Pemasaran hasil produksi tenun Unggan, yang dikarenakan jarak yang cukup jauh untuk menuju Nagari Unggan dari Kabupaten Sijunjung saja memakan waktu 2 sampai 3 jam ditambah dengan infrastruktur jalan yang kurang memadai yang berdampak pada pengurangan minat konsumen untuk datang ke gedung sentra tenun songket Unggan. Dan yang terakhir modal yang terbatas bagi UMKM dan teknologi produksi dimana untuk memulai usahanya pengra

Berdasarkan uraian di atas, maka penulis tertatik untuk meneliti pembinaan sentra tenun songket Unggan oleh 


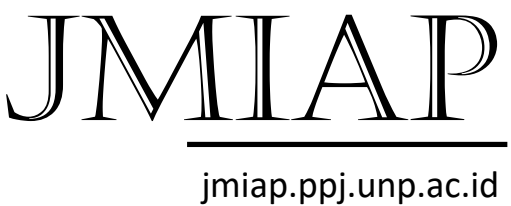

Pemerintah Kabupaten Sijunjung dengan rumusan masalah yaitu :

1) Bagaimana pembinaan sentra tenun songket Unggan oleh pemerintah Kabupaten Sijunjung?

2) Apa kendala yang dialami pemerintah dalam pembinaan sentra tenun songket Unggan?

\section{Tinjauan Kepustakaan}

Peranan Pemerintah dalam Pembangunan UMKM

Sebagaimana yang diungkapkan oleh Soekanto (2014), peran merupakan aspek dinamis kedudukan (status), apabila seseorang melaksanakan hak dan kewajibannya sesuai dengan kedudukannya, maka ia menjalankan suatu peranan. Menurut Rasyid (2000:48) pelaksanaan pemerintahan yang baik selalu berpatokan pada peran pemerintah yang diatur oleh peraturan yang ditentukan dan pelaksanaan peran tersebut tergantung pihak pemimpinnya sendiri. Dalam hal ini kegiatan yang harus dilaksanakan / dijalankan terdapat tiga peran yang hakiki yaitu : Pelayanan (service), Pemberdayaa (Empowerment) dan Pembangunan ( Development). pengertian peranan pemerintah diatas menegaskan bahwa apabila pemerintah telah melaksanakan hak dan kewajibannya sesuai dengan kedudukannya berarti dia sudah menjalankan suatu perananan seperiti peran pemerintah sebagai pelayanan, pemberdaya serta pembangunan.

Menurut Gede Diva, 2009:15-18 dalam Putra (2015) dalam pengembangan UMKM peranan pemerintah yang efektif dan optimal diwujudkan sebagai Fasilisator, Regulator dan Katalisator

1) Peran pemerintah sebagai fasilisator
JURNAL ILMU ADMINISTRASI PUBLIK

Email : jianfis.unp@gmail.com

Vol.1 No.1 Tahun 2018

Pemerintah berperan dalam memfasilitasi UMKM yang bertujuan agar usaha yang dimiliki UMKM tersebut dapat berkembang. Sebagai fasilisator pemerintah juga membantu UKM dalam mengatasi permasalahpermasalahan yang ada seperti jika UMKM mempunyai kelemahan di bidang produksi, tugas fasilisator adalah memberikan pelatihan. Demikian pula jika UMKM lemah dalam hal pendanaan, tugas fasilisator adalah membantu mencari jalan keluar agar UMKM mampu mendapatkan pendanaan yang dibutuhkan, tetapi harus dilakukan secara hati-hati agar posisi UMKM menjadi tidak ketergantungan.

2) Pemerintah Sebagai Regulator

Peranan pemerintah sebagai regulator yaitu membuat kebijakan-kebijakan yang bertujuan untuk mempermudah UMKM dalam pengembangan usahannya. Seperti membuat kebijakan tentang persaingan usaha, karena pemerintah merupakan pihak yang mampu menerapkan aturan agar kehidupan dapat berjalan dengan baik dan dinamis.

3) Pemerintah Sebagai Katalisator

menurut kamus KBBI katalisator adalah seseorang atau sesuatu yang menyebabkan terjadinya perubahan dan menimbulkan kejadian baru atau mempercepat suatu peristiwa. Berdasarkan ungkapan tersebut, peran pemerintah daerah sebagai katalisator dalam pengembangan UMKM yaitu mempercepat proses berkembangnya UMKM menjadi Fast Moving Enterprise. Fast Moving Enterprise. Dalam mencapai perkembangan fast moving enterprise, dalam hal ini pemerintah menjalankan perannya

Haryani Harsari, Afriva Khaidir |157 


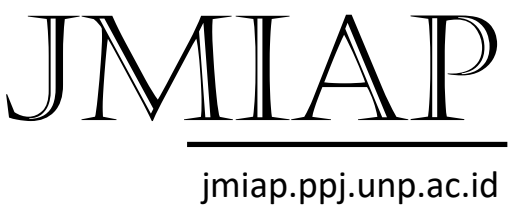

sebagai katalisator, ada beberapa hal yang dilakukan oleh pemerintah dalam pengembangan UMKM seperti pemberdayaan komunitas kreatif untuk produktif bukan konsumtif, penghargaan terhadap UMKM, prasarana intelektual bagi UMKM (perlindungan hak kekayaan intelektual) serta adanya bantuan permodalan.

Berdasarkan penjelasan di atas tersebut dapat ditarik kesimpulan bahwa perananan merupakan hak dan kewajiban yang telah dilaknsanakan oleh pemerintah sesuai dengan kedudukannya.

Berdasarkan penjelesan tersebut dapat disimpulkan bahwa pemerintah mempunyai peranan yang sangat luas, salah satunya peranan pemerintah dalam pembangunan UMKM seperti adanya penyedian sarana dan prasarana untuk pengembangan UMKM, dan pemerintah juga berperan serta dalam memberikan pembinaan terhadap UMKM untuk mempercepat proses berkembangnya UMKM

Tujuan pembangunan sentra tenun songket unggan

Sentra industri kecil dan menengah (sentra IKM) merupakan lokasi pemusatan kegiatan industri kecil, menengah yang menghasilkan produk yang sejenis, bahan baku sejenis dan juga mengerjakan proses produksi yang sama, serta dilengkapi sarana dan prasarana pendukung berbasis pada pengembangan ptensi sumber daya daerah, dimana dikelola oleh suatu pengurus profesional. Pengembangan sentra IKM merupakan amanah di dalam undang-undang No 3 Tahun 2014 tentang perindustrian, dimana pasal 14 menyebutkan peranan pemerintah pusat dan/atau Pemerintah Daerah melakukan
JURNAL ILMU ADMINISTRASI PUBLIK

Email : jianfis.unp@gmail.com

Vol.1 No.1 Tahun 2018

percepatan pembangunan industri ke seluruh wilayah negara Kesatuan Republik Indonesia melallui perwilayahan industri.

Pada saat ini sentra IKM umumnya tumbuh secara informal dengan berbagai keternatasannya, tanpa sentuhan dan campur tangan lamgsung pemerintah sehingga sangat sulit untuk berkembang pemerintah dan/atau Pemerintah Daerah diharapkan melakukan pembangunan dan pemberdayaan IKM untuk mewujudkan IKM yang berdaya saing, berperan signifikan dalam penguatan struktur Industri nasional (PPI Kementrian Perindustrian). Berdasarkan yang dimuat dalam PPI Kementrian Perindustrian ada beberapa tujuan dalam pengembangan sentra IKM yaitu:

Tujuan Pengembangan Sentra IKM

1. Mempercapat persebaran dam pemerataan IKM

2. Mendorong tumbuhnya IKM modern

3. Meningkatkan daya saing IKM

4. Meningkatkan upaya pembangunan IKM yang berwawasan lingkungan

5. Meningkatkan jaringan bisnis/kerjasama dan

6. Meyediakan sarana dan prasarana terpadu bagi IKM

Berdasarkaan hal tersebut dapat disimpulkan pembangunan terhadap UKM sangat diperlukan terutama untuk mneingkatan APBD dan peningkatan ekonomi masyarakat pelaku UKM

\section{Kendala dalam pengembangan UKM}

menurut Hafsah (2004) dalam Jauhari (2010) kendala yang ditemui dalam pengembangan UKM adalah sebagai berikut:

1) Kurangnya Permodalan

Permodalan merupakan faktor yang sangat utama diperlukan dalam 
mengembangkan suatu unit usaha. Kurangnya permodalan UKM disebabkan karena pada umumnya usaha kecil dan menengah merupakan usaha perorangan atau perusahaan yang sifatnya tertutup, dimana modalnya mengandalkan pada modal dari si pemilik yang jumlahnya juga sangat terbatas, sedangkan modal pinjaman yang bersumber dari bank atau lembaga keuangan lainnya sulit untuk diperoleh, sebab modal pinjaman dari bank atau lembaga keuangan lainnya sulit untuk diperoleh, karena salahsatunya persyaratan secara administratif dan teknis yang diminta oleh bank tidak dapat dipenuhi

2) Sumber Daya Manusia (SDM) yang sangat terbatas

Kebanyakan usaha kecil tumbuh secara tradisional dan merupakan usaha keluarga yang turun temurun. Keterbatasan SDM usaha kecil baik dari segi pendidikan formal maupun pengetahuan dan keterampilannya sangat berpengaruh terhadap manajemen penglolaan usahanya, sehingga usaha tersebut sulit untuk berkembang dengan optimal. Di samping itu dengan keterbatasan SDM-nya, unit usaha tersebut relatif sulit untuk mengadopsi perkembangan teknologi baru untuk meningkatkan daya saing produk yang dihasilkannya.

3) Lemahnya Jaringan Usaha dan Kemampuan Penetrasi Pasar

Usaha kecil yang pada umumnya merupakan unit usaha keluarga, mempunyai jaringan usaha yang sangat terbatas dan kemampuan penetrasi pasar yang rendah, oleh karena produk yang dihasilkan jumlahnya sangat terbatas dan mempunyai kualitas yang kurang kompetitif. Berbeda dengan usaha besar yang telah mempunyai jaringan yang sudah solid serta didukung dengan teknologi yang dapat menjangkau internasional dan promosi yang baik.

4) Terbatasnya Akses Pasar

Terbatasnya akses pasar akan menyebabkan produk yang dihasilkan tidak dapat dipasarkan secara kompetitif baik di pasar nasional maupun pasar internasional

Berdasarkan pendapat Setyobudi (2007) dalam Munizu (2013) membagi permasalahan UKM dalam tiga kategori yakni:

1) Permasalahan yang bersifat klasik dan mendasar pada UKM (basic problems), antara lain berupa permasalahan modal, bentuk badan hukum yang umumnya non formal, SDM, pengembangan produk dan akses pemasaran.

2) Permasalahan lanjutan (advancedproblems), antara lain pengenalan dan penetrasi pasar ekspor yang belum optimal, kurangnya pemahaman terhadap desain produk yang sesuai dengan karakter pasar, permasalahan hukum yang menyangkut hak paten, prosedur kontrak penjualan serta peraturan yang berlaku di Negara tujuan ekspor.

3) Permasalahan antara (intermediate problems), yaitu permasalahan dari instansi terkait untuk menyelesaikan masalah dasar agar mampu menghadapi persoalan lanjutan secara lebih baik. Permasalahan tersebut antara lain dalam hal manajemen keuangan, agunan dan keterbatasan

Haryani Harsari, Afriva Khaidir |159 
dalam kewirausahaan. Dengan pemahaman atas permasalahan di atas, akan dapat ditengarai berbagai problem dalam UKM dalam tingkatan yang berbeda, sehingga solusi dan penanganannya pun seharusnya berbeda pula.

dapat dsimpulkan bahwa kendala ataupun permasalahan dalam pengembangan UMKM tersebut bisa bersumber dari faktor internal ataupun eksternalnya akan tetapi pada umumnya salah satu faktor utama penghambat dari pengembangan UMKM adalah Modal karena untuk memulai suatu usaha pasti memerlukan modal. Dan sumber daya manusia juga merupakan aspek yang penting juga karena manusia yang akan menjalankan suatu unit usaha maka dari itu pemerintah sangat berperan dalam melakkan pembinaan terhadap sumber daya manusia salah satunya dengan melakukan pemberdayaan untuk peningkatan kualitas SDM agar lebih inovatif dan kreatif.

\section{Metode Penelitian}

Dalam penelitian ini meggunakan penelitian kualitatif dengan metode deskriptif, yang akan mendeskripsikan, mencatat, menjelaskan dan memaparkan pembinaan sentra produksi tenun songket Unggan oleh pemerintah Kabupaten Sijunjung. Lokasi penelitian ini dilakukan di Kabupaten Sijunjung khususnya di kantor Dinas perdagangan, perindustrian, koperasi usaha kecil dan Menengah, Kabupaten Sijunjung, Lokasi sentra tenun Unggan Kecamatan Sumpur Kudus, yang bersangkutan dengan penelitian ini. Alasan pemilihan Kabupaten Sijunjung dalam penelitian ini adalah karena Kabupaten sijunjung memiliki potensi pariwisata yang sangat besar terutama dalam objek wisata alam dan wisata adatnya, apabila banyak wisatawan yang berkunjung ke sijunjung maka juga akan membuka peluang yang besar dalam memasarkan produk khas dari daerah Sijunjung.

Pada penelitian ini teknik pengumpulan data yang digunakan adlah teknik purposive. Pemilihan informan didasarkan pada karakteristik tertentu, yaitu pada orang-orang yang memahami dan berhubungan langsung dengan permasalahan penulis teliti. Sumber data dalam penelitian ini menggunakan sumber data primer dan data sekunder, data primer didapat dari hasil wawancara dan observasi dengan informan penelitian yang terkait dengan pembinaan sentra tenun songket Unggan oleh pemerintah Kabupaten Sijunjung dalam pembinaan sentra tenun songket Unggan termasuk kendala-kendala yang dihadapi sedangkan dari data sekunder diperoleh dari data yang bersumber dari bacaan dan mempunyai keterkaitan dalam masalah yang peneliti teliti, seperti buku-buku, jurnal ilmiah, hasil penelitian, peraturan dan perundangundangan, informasi, media masa dan berbagai data statistik yang berkaitan dengan pembinaan sentra tenun songket Unggan oleh pemerintah Kabupaten Sijunjung. Teknik pengumpulan datanya dilakukan dengan Interview (wawancara), observasi dan juga dokumentasi. Teknik pengujian keabsahan data menggunakan trianggulasi sumber. Sedangkan teknik analisis data Sedangkan teknik analisis data mengacu pada teknik yang dikembangkan oleh Miles dan Huberman, yaitu pengumpulan data, reduksi data, penyajian data (display data), dan penarikan kesimpulan/verifikasi.

\section{Hasil Penelitian dan Pembahasan Hasil Penelitian}

Berdasarkan penelitian yang telah dilakukan di lapangan tentang pembinaan 


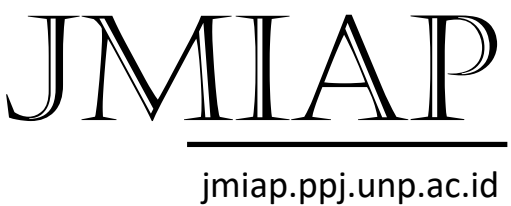

JURNAL ILMU ADMINISTRASI PUBLIK

Email : jianfis.unp@gmail.com

Vol.1 No.1 Tahun 2018

sentra tenun songket Unggan oleh pemerintah Kabupaten Sijunjung dijelaskan sebagai berikut:

Adapun tujuan dari pembangunan Sentra tenun Songket Unggan di Kabupaten Sijunjung adalah sebagai berikut :

1) Meningkatkan nilai tambah produksi pengrajin Songket Unggan, sehingga dapat memenuhi banyaknya permintaan saat ini dan dimasa yang akan datang.

2) Mendekatkan produk tenung songket Unggan ke pasar (market) dan diterima konsumen lebih luas.

3) Menumbuhkan minat masyarakat awam yang tidak memiliki keahlian menenun utuk mau mempelajari dan menjadi pengrajin tenun Songket Unggan.

4) Meningkatkan kualitas tenun songket Unggan sehingga dapat bersaing dengan kerajinan songket dari daerah lain dan lebih menarik minat konsumen untuk membeli hasil tenun Songket Unggan.

5) Meningkatkan pendapatan dan kesejahteraan pengrajin songket Unggan.

6) Memenuhi permintaan untuk kebutuhan Industri Dalam Negeri.

7) Peningkatan PAD Kabupaten Sijunjung. (Pindahkan ke Temuan)

Dalam pembinaan sentra tenun songket Unggan pemerintah berperan sebagai fasilisator, regulator dan juga katalisator sebagaimana yang telah dikemukakan oleh Gede Diva, 2009:15-18 dalam Putra (2015) yaitu:

a)Sebagai fasilisator

Berdasarkan hasil wawancara peneliti di lapangan pada Dinas Perdagangan Perindustrian Koperasi Usaha Kecil dan Menengah dalam pengembangan sentra tenun songket Unggan pemerintah mempunyai peranan dalam memfasilitasi pengrajin dalam kegiatan menenun dan bentuk fasilitas yang telah diberikan oleh pemerintah dalam pengembangan sentra tenun songket Unggan yaitu yang pertama dalam segi fasilitas sarana dan prasarana pemerintah memfasilitasi penenun dengan adanya pembangunan gedung sentra selain itu pemerintah juga menyediakan alat dan mesin untuk menunjang kegiatan menenun, yang kedua pemerintah memfasilitasi pengrajin dalam pelatihan keterampilan dan desain dimana adanya pelaksanaan pelatihan atau diklat yang diberikan pemerintah kepada pengrajin selain itu pemerintah juga bekerjasama dengan ISI Padang Panjang salahsatunya dalam diversifikasi produk dan juga pematenan 30 motif tennun Unggan. Dan yang ketiga pemerintah memfasilitasi pengrajin dengan fasilitas pemasaran dimana pemerintah juga membantu dalam pemasaran produk tenunan Unggan dalam bentuk adanya pameran-pameran yang diadakan oleh pemerintah selain itu seluruh ASN di Kabupaten Sijunjung juga diwajibkan untuk memakai baju dari tenunan Unggan. Berdasarkan informasi yang peneliti dapat dilapangan, bahwa pemerintah melalui Dinas Perdagangan Perindustrian Koperasi Usaha Kecil dan Menengah juga telah mengupayakan pembangunan jalan untuk menuju gedung sentra tenun Unggan dan juga mengupayakan penambahan pembangunan gedung yang terintegrasi dengan kegiatan menenun.

b) Peran pemerintah sebagai regulator

Peran pemerintah dalam pembinaan UMKM sentra tenun songket Unggan sebagai regulator yeitu adanya peraturan Bupati Nomor 37 Tahun 2016 tentang Kedudukan, susunan. Organisasi, tugas dan fungsi serta tata kerja pada Dinas

Haryani Harsari, Afriva Khaidir |161 


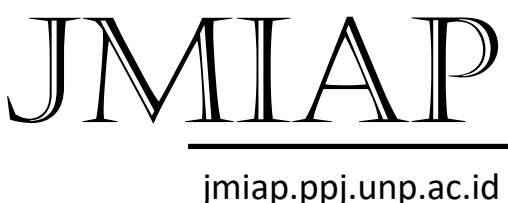

jmiap.ppj.unp.ac.id
JURNAL ILMU ADMINISTRASI PUBLIK

Email : jianfis.unp@gmail.com

Vol.1 No.1 Tahun 2018
Perdagangan Perindustrian Koperasi Usaha Kecil dan Menengah, serta yang dimuat dalam Renstra Dinas Perdagangan Perindustrian Koperasi Usaha Kecil Dan Menengah Kabupaten Sijunjung. dimana dalam renstra tersebut menjelaskan bahwa karena belum optimalnya perkembangan sentra-sentra industri potensial dalam rangka peningkatan efisiensi dan produktivitas dinas Dagperinkop mempunyai program-progam dalam peningkatan IKM seperti adanya program pengembangan industri kecil dan menengah berbasis potensi lokal dan sentra, pengembangan industri tenun berbasis sentra, pengembangan kelembagaan sentra tenun dimana indikator kinerja program dan kegiatan untuk peningkatan jumlah sentra yang dikembangkan, serta penguatan kemampuan industri berbasis teknologi tepat guna dengan meningkatkan jumlah mesin dan peralatan industri yang diadakan. c) peran pemerintah sebagai katalisator

Berdasarkan hasil temuan peneliti dilapangan dari hasil informasi yang diperoleh dapat diketahui bahwa peranan pemerintah sebagai katalisator yang pertama dalam peningkatan Sumber Daya Manusianya pemerintah berupaya dalam memberikan pelatihan/diklat kepada penenun selain itu pemerintah juga mengajak perempuan-perempuan yang pada umumnya tamatan SMA yang masih sangat produktif dan juga ibu-ibu muda yang yang tidak mempunyai pekerjaan untuk dilatih dalam kegiatan menenun agar mereka mempunyai kegiatan untuk menambah pemasukan ekonominya karena pada saat ini tenunan Unggan merupakan salah satu produk unggulan di Kabupaten Sijunjung. Pemerintah juga bekerja sama dengan ISI padang Panjang dalam diversivikasi produk serta desainer terkemuka Samuel Watimetta, agar para pengrajin tersebut lebih inovatif. Oleh ISI Padang Panjang penenun diajarkan untuk berinovasi bagaimana cara untuk mengolah produk kerajinan tenun Unggan dijadikan ke dalam bentuk yang bervariasi seperti dalam membuat lukisan dinding, membuat sajadah, peci, dompet dan sebagainya. Pemerintah juga ikut serta membantu memberikan permodalan dan memasarkan produk tenunan Unggan. bantuan modal yang diberikan pemerintah berupa fasilitas sarana dan prasarana pembangunan gedun sentra tenun songket Unggan yang dilengkapi dengan alat/mesin untuk kegiatan menenun kepada pengrajin sedangkan dalam pemasaran produk tenunan Unggan dimana pemerintah mengikutsertakan tenunan Unggan pada pameran-pameran yang diadakan pada saat hari jadi Kabupaten Sijunjung, dan adanya aturan tentang mewajibkan memakai baju tenun Unggan bagi seluruh Pegawai Negeri Sipil di Kabupaten sijunjung. Pemerintah tidak hanya bekerja sama dengan orangorang yang bisa memberikan pelatihan keterampilan dan desain saja tetapi pemerintah juga betul-betul mengambil narasumber yang dirasa juga mampu utuk membantu dalam pemasaran.

Kendala dalam pembinaan sentra tenun songket Unggan

Berdasalkan penelitian yang telah dilakukan di lapangan kendala dalam pembinaan sentra tenun songket Unggan oleh pemerintah Kabupaten Sijunjung adalah

ada beberapa kendala yang membuat pengembangan sentra tenun Unggan masih belum maksimal.

Menurut Hafsah (2004) dalam Jauhari (2010) mengemukakan ada empat permasalahan dalam UKM yaitu:

a) Kurangnya permodalan 


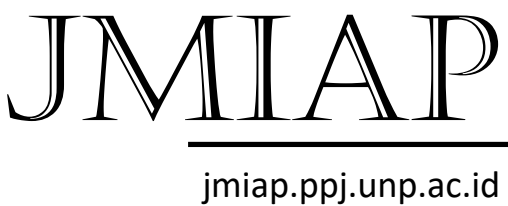

Modal yang terbatas baik itu dari pemerintah ataupun pengrajin. Modal yang diberikan oleh pemerintah berupa benang yang diberikan ke gedung sentra bantuan benang tesebut memang tidak dilakukan secara berlanjut atau kontinue, hal itu diakibatkan karena anggaran dari pemerintah juga terbatas dan juga pemerintah ingin agar pengrajin tersebut bisa lebih mandiri. sedangkan pengrajin tenun Unggan sendiri juga sangat sulit untuk mengembangkan usaha mereka yang diakibatkan oleh keterbatasan dana sehingga menyebabkan mereka sulit untuk melakukan inovasi dalam produk

b) SDM (sumber daya manusia)

Terganjal dengan pola pikir masyarakatnya yang masih agraris, walaupun dari tahun ke tahun jumlah pengrajin tenun Unggan meningkat terkadang juga mengalami penunurunan karena kurangnya keseriusan pengrajin dalam bertenun atau bertenun hanya sekedar ikut-ikutan, apabila adanya keseriusan dari masyarakat yang benarbenar ingin menekuni kegiatan bertenun juga berdampak pada penambahan pemasukan ekonomi keluarga selain itu kurangnya manajemen sumber daya manusia dan juga adanya ketidakmampuan atau kurangnya koordinasi dan kerjasama antar kelompok sehingga menyebabkan dampak pada kemunduran dari pengembangan gedung sentra tenun Unggan, dimana gedung sentra tidak berjalan sebagaimana mestinya yang berdampak pada kurangnya minat penenun untuk menenun di gedung sentra karena bahan-bahan yang sudah dipproduksi menjadi kain tidak mampu dipasarkan atau dikelola dengan baik oleh anggota kelompok sehingga menyebabkan modal awal tidak berputar untuk membeli bahan selanjutnya atau untuk modal berikutnya.
JURNAL ILMU ADMINISTRASI PUBLIK

Email : jianfis.unp@gmail.com

Vol.1 No.1 Tahun 2018

c) Lemahnya jaringan usaha dan Kemampuan Penetrasi Pasar

Diakibatkan karena belum adanya tempat pemasaran dari hasil tenunan Unggan atau outlet khusus pemasaran produk tenunan Unggan sehingga menyebabkan pengarajin mengalami kesulitan dalam pemasaran produk terlebih lagi jika tidak ada pesanan pengrajin terkadang tidak menenun karena tidak adanya modal, yang diakibatkan oleh kain tenun yang sudah diolah tidak terjual karena hasil dari penjualan tersebut digunakan untuk menutupi modal selanjutnya. Selain itu produk tenunan Unggan masih belum kompetitif dikarenakan banyakanya produk yang sejenis dipasaran dengan harga yang lebih murah, dan masih kurang mandiri dimana pengrajin tenun Unggan masih memasok bahan baku ke silungkang yang dikarenakan karena di Unggan belum adanya alat pemintal benang.

d) Terbatasnya akses pasar

Dalam memasarkan produk tenunan Unggan pengrajin harus menmpuh jarak yang cukup jauh, dan infrastruktur jalan yang masih belum memadai untuk menuju pasar. Dan juga adanya kesulitan dalam distribusi dan pengadaan bahan baku, keterbatasan akses informasi mengenai peluang pasar dan lainnya. Karena pada umumnya pengrajin tenun Unggan tidak punya sumber-sumber daya untuk mencari ataupun mengembangkan pasar mereka sendiri. Biasanya untuk memasarkan produknya pengrajin hanya bergantung kepada konsumen yang datang ketempat mereka memprodksi produk tenunan Unggan.

\section{Pembahasan}

Berdasarkan hasil penelitian yang telah diuraikan sebelumnya bahwa pembinaan sentra produksi tenun Unggan oleh

Haryani Harsari, Afriva Khaidir |163 


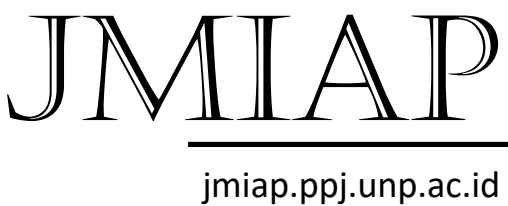

jmiap.ppj.unp.ac.id
JURNAL ILMU ADMINISTRASI PUBLIK

Email : jianfis.unp@gmail.com

Vol.1 No.1 Tahun 2018 pemerintah Kabupaten Sijunjung berupa fasilisator, regulator dan juga katalisator. Peranan yang lebih dominan oleh pemerintah dalam pembinaan sentra tenun songket Unggan yaitu sebagai fasilisator, dengan demikian hasil penelitian ini dapat membuktikan teori yang dikemukakan oleh

Gede Diva, 2009:15-18 dalam Putra (2015) yang mengatakan ada beberapa peranan dalam pengembangan UKM antara lain yaitu: sebagai fasilisator Menurut Gede Diva, 2009:15-18 dalam putra 2015 Sebagai fasilisator, pemerintah memiliki peran dalam memfasilitasi UMKM untuk mencapai tujuan pengembangan usaha yang dimiliki oleh UMKM Peran Dinas Perdagangan Perindustrian Koperasi Usaha Kecil dan Menengah sebagai fasilisator sudah diupayakan terutama dengan adanya pembangunan gedung sentra yang bisa dipergunakan oleh pengrajin untuk menenun dan memasakan produk tenunan Unggan, adanya pelatihan keterampilan dan desain yang diberikan oleh pemerintah dan terakhir pemerintah juga membantu dalam memasarkan produk tenunan Unggan.

Sedangkan sebgai Regulator pemerintah berperan dalam membuat kebijakan-kebijakan pada penelitian ini peran pemerintah sebagai regulator adanya peraturan Bupati Nomor 37 Tahun 2016 tentang Kedudukan, susunan. Organisasi, tugas dan fungsi serta tata kerja pada Dinas Perdagangan Perindustrian Koperasi Usaha Kecil dan Menengah dan renstra dinas perdagangan perindustrian koperasi usaha kecil dan menengah yang mempunyai program-progam dalam peningkatan IKM seperti adanya program pengembangan industri kecil dan menengah berbasis potensi lokal dan sentra dan terakhir menurut Gede Diva, 2009:15-18 dalam putra 2015 peranan pemerintah dalam pengembangan UKM sebagai katalisator yaitu mempercepat perkembangan UKM salah satunya dengan peningkatan jumlah sumber daya manusianya, meningkatkan kualitas sumber daya manusia dengan mengadakan pelatihan atau diklat dan pemerintah membantu dalam memberikan permodalan dan pemasaran. Sedangkan kendala- kendala yang ditemui di lapangan dalam hasil penelitian ini dikemukan oleh Menurut teori Hafsah (2004) dalam Jauhari (2010) mengemukakan ada empat permasalahan dalam UKM 1) Kurangnya permodalan, baik oleh pemerintah ataupun pengrajin 2) Sumber Daya Manusia (SDM) yang terbatas, berdasarkan pada penelitian ini jumlah SDM pengrajin tenun Unggan masih terbatas dikarenakan seiring dengan berjalannya waktu jumlah pengrajin juga semakin berkurang 3) Lemahnya jaringan usaha dan kemampuan penetrasi pasar, 4) Terbatasnya akses pasar.

Dengan demikian, hasil penelitian ini membuktikan dan memperkuat teori yang telah dikemukakan oleh Gede Diva, 2009:15-18 dalam Putra (2015) yang menyatakan bahwa dalam pengembangan UMKM peranan pemerintah yang efektif dan optimal diwujudkan sebagai Fasilisator, Regulator dan Katalisator. Hasil penelitian ini juga membuktikan teori yang dikemukakan oleh Hafsah (2004) dalam Jauhari (2010) yang mengatakan bahwa kendala dalam pembinaan UMKM yaitu 1) Kurangnya permodalan, 2) SDM yang terbatas, 3) Lemahnya jaringan usaha dan kemampuan penetrasi pasar 4) Terbatasnya akses pasar.

\section{Penutup}

\section{kesimpulan}

Berdasarkan hasil penelitian dan pembahasan yang peneliti lakukan maka dapat ditarik kesimpulan sebagai berikut :

Haryani Harsari, Afriva Khaidir |164 
1. pembinaan sentra tenun songket Unggan oleh pemerintah di Kabupaten Sijunjung sudah sedikit maksimal, terlihat dari peranan yang telah dilaksanakan yaitu sebagai fasilisator, regulator dan juga katalisator.

a) Peran pemerintah sebagai fasilisator, Peranan pemerintah sebagai fasilisator yaitu pembangunan fasilitas sarana dan prasaran berupa pembangunan gedung sentra, adanya pemberian pelatihan dan keterampilan dan desain yang dilaksanakan oleh pemerintah dan yang terakhir pemerintah berperan dalam memberikan fasilitas pemasaran kepada pengrajin tenunan Unggan

b) Peran pemerintah sebagai regulator adalah membuat kebijakankebijakan sehingga mempermudah usaha UMKM dalam mengembangkan usahannya dalam pengembangan sentra tenun Unggan. dibuktikan dengan adanya peraturan Bupati Sijunjung Nomor 37 Tahun 2016 dimana peraturan tersebut mengandung tentang Kedudukan, Susunan Organisasi, Tugas dan Fungsi serta Tata Kerja pada Dinas Perdagangan Perindustrian Koperasi Usaha Kecil dan Menengah. Peraturan tersebut bertujuan untuk membantu Kepala Daerah dalam melaksanakan pembinaan, koordinasi dan pengawasan pelaksaanaan pembangunan koperasi, usha mikro kecil dan menengah. Dan renstra dinas perdadangan perindustrian koperasi usaha kecil dan menengah

c) Peran pemerintah sebagai katalistor adalah dengan meningkatkan dan mengembangkan kualitas SDM, pemerintah telah bekerja sama dengan BDI atau balai diklat industri dan juga bekerja sama dengan ISI Padang Panjang, dan juga pemerintah juga memprioritaskan kaum perempuan anak putus sekolah yang tamat SMA dan juga juga ibuibu muda.

2. Kendala dalam pengembangan sentra tenun songket Unggan di Kecamatan Sumpur Kudus Kabupaten Sijunjung

Pertama dari permodalan, karena untuk memualai usaha seperti membeli bahan dan alat tentunya pengrajin membutuhkan modal awal untuk memulai usahannya bantuan modal dari pemerintah pun juga masih belum bisa dirasakan oleh seluruh pengrajin karena pemerintah sendiri juga terkendala dengan terbatasnya anggaran. Yang kedua dari sisi SDM (sumber daya manusia) masih terganjal dengan pola pikir masyarakatnya yang masih agraris, selain itu kurangnya manajemen sumber daya manusia, Yang ketiga lemahnya jaringan usaha dan Kemampuan Penetrasi Pasar karena belum adanya tempat pemasaran dari hasil tenunan Unggan atau outlet khusus pemasaran produk tenunan Unggan Yang keempat masih terbatasnya akses pasar dimana Terbatasnya akses pasar akan menyebabkan produk yang dihasilkan tidak dapat dipasarkan secara kompetitif baik di pasar nasional maupun pasar internasional. Dan juga adanya kesulitan dalam distribusi dan pengadaan bahan baku, keterbatasan 
akses informasi mengenai peluang pasar dan lainnya.

\section{B. Saran}

1. Pemerintah

Kepada pemerintah agar memperhatikan kebutuhan pelaku UMKM pengrajin Tenun Unggan. Terutama pada masalah Sumber Daya Manusianya untuk lebih meningkatkan dan mengembangkan SDM dari para Pengrajin untuk mampu melakukan inovasi terhadap produk mereka, sedangkan untuk pemasaran dan promosi produk tenunan Unggan diharapkan kepada pemerintah berupaya dalam menyediakan outlet khusus pemasaran tenunan Unggan, karena apabila ada outlet khusus untk pemasaran prduk tenunan Unggan maka akan mudah bagi pengrajin untuk memasarkan produk mereka, dan pemerintah diharapkan untuk segera memperbaiki infrastruktur jalan menuju lokasi sentra tenun songet Unnggan, karena jalan yang kecil dan rusak dikhawatirkan akan mengurangi minat konsumen ataupun wisatawan untuk mengunjungi gedung sentra

2. Pelaku pengrajin tenun Unggan

Untuk pengrajin tenun Unggan agar dapat untuk lebih berinovasi dalam pengembangan produk tenun Unggan, dan juga kepada pengrajin agar lebih serius untuk mengembangkan tenun Unggan dan juga harus lebih lagi dalam peningkatan kualitas dan mutu produk mengingat tenunan Unggan merupakan salah satu produk Unggulan Kabupaten Sijunjung dan diharapkan kepada pengrajin agar mempertahankan apa yang sudah menjadi ciri khas kerajinan tenun Unggan. Dan juga diharapkan kepada pengrajin agar dapat bekerja sama dengan pihak lain tidak hanya pada pemerintah saja, agar kerajinan tenun Unggan bisa dikenal masyarakat banyak baik yang berasal dari dalam daerah maupun luar daerah.

\section{DAFTAR PUSTAKA}

Rasyid, Muhammad Ryaas, 2000, makna pemerintahan. Tinjauan dari segi etika dan kepemimpinan. Jakarta : PT. Mutiara Sumber Widya

Soekanto, Soerjono, dkk. 2014. Sosiologi Suatu Pengantar. Jakarta : PT Rajagrafindo Persada

Musran, Munizu. 2010. Pengaruh Faktorfaktor Eksternal dan Intenal Terhadap Kinerja Usaha Mikro dan Kecil (UMK) di Sulawesi Selatan. Jurnal Manajemen dan Kewirausahaan Volume 12 Nomor 1

Jauhari, Jaidan. 2010. Upaya Pengembangan Usaha Kecil Dan Menengah (UKM) Dengan Memanfaatkan EComerce. Jurnal Sistem Informasi (JSI) Volume 2 Nomor 1

Musran, Munizu. 2013. Strategi Peningkatan kinerja Dan peran Usaha Kecil Dan Menengah (UKM) Pengolah Produk Berbasis Pangan. Journal Management Of Business Volume 12 Nomor 1

Putra, Gani, Taranggana. 2015. Peran Pemerintah Daerah Dan Psrtisipasi Pelaku Usaha Dalam Pengembangan UMKM ManikManik Kaca Di Kabupaten Jombang. Jurnal Kebijakan dan Manajemen Publik Volume 3, Nomor 1

\section{Undang-undang dan terkait resmi}


JMIAP

Peraturan Bupati Sijunjung Nomor 37 Tahun 2016 tentang kedudukan, susunan organisasi, tugas dan fungsi serta tata kerja pada Dinas Perdagangan, Perindustrian, Koperasi Usaha Kecil dan Menengah.

Undang-undang No 3 Tahun 2014 tentang Perindustrian,
JURNAL ILMU ADMINISTRASI PUBLIK

Email : jianfis.unp@gmail.com Vol.1 No.1 Tahun 2018

Renstra Dinas Perdagangan dan perindustrian Koperasi Usaha Kecil dan Menengah Artikel di internet

Website

Kabupaten

Sijunjung https://www.sijunjung.go.id/v2/

Badan Pusat Statistik Sijunjung 2018 https://sijunjungkab.bps.go.id

Website kementrian Perindustrian Republik Indonesia

http://www.kemenperin.go.id 